\title{
Notes
}

\section{Statehood and the Equal Footing Doctrine: The Case for Puerto Rican Seabed Rights}

\author{
In the near future, negotiations between Puerto Rico and the
} United States will probably explore statehood as an alternative to the island's current "commonwealth" status. ${ }^{1}$ The island's dearth of land-

1. Commonwealth status means the island enjoys self-government in local affairs under its own constitution and association with the United States under the Puerto Rican Federal Relations Act of 1950, $\S \S 1,4,48$ U.S.C. $\$ \S 731(b), 731$ (e) (1970). For a discussion of the continuing debate concerning the nature of commonwealth status, see Cabranes, Puerto Rico: Out of the Colonial Closet, Foreign PoL'y, Winter 1978, at 66.

The island's ongoing economic difficulties have exacerbated dissatisfaction with the commonwealth arrangement and the island's political parties are voicing demands for a status change. See, e.g., Garcia Passalacqua, 20 Years of Anticolonialism, San Juan Star, Apr. 23, 1977, at 27, col. 2 (attacks on commonwealth status have brought "[c]olonialism in Puerto Rico" to "its deathbed"); Puerto Rican Factions Hit Island Status, Wash. Post, Aug. 19, 1977, at Al, col. 6 ("For the first time, virtually the whole spectrum of political opinion in Puerto Rico appeared before a U.N. committee . . . and criticized the island's commonwealth status.")

Statehood is currently the foremost alternative to the "fast collaps[ing]" commonwealth. Garcia Passalacqua, Hispanic State or La Republica-IV, San Juan Star, Mar. 3, 1977, at 27, col. 2. The island's statehood parties since 1952 have received increasingly larger percentages of the vote, culminating in the $48.3 \%$ that they received in 1976 . See Letter from Michael E. Veve, Director, Legal Counsel Section of the Office of the Commonwealth of Puerto Rico to José A. Cabranes, Lecturer in Law, Yale Law School (Mar. 28, 1978) (on file with Yale Law Journal). Although this percentage partly reflected protests against the island's economic state under the commonwealth party, the trend toward statehood is clear. Puerto Rico: the oil issue, 11 Latin America Political Rep., Feb. 4, 1977, at 38 .

President Ford's New Year's Eve statehood proposal suggests some United States support for the statehood alternative. See President Proposes Puerto Rican State; Urges U.S. Initiative, N.Y. Times, Jan. 1, 1977, at 1, col. 6. President-elect Carter indicated his willingness to support statehood " 'if the people who live there prefer that." "Carter Weighing Personnel to Fill Sub-Cabinet Jobs, N.Y. Times, Jan. 2, 1977, at 1, col. 5 \& 44, col. 5. A Gallup poll conducted in December 1976 found three out of every five Americans in favor of statehood for Puerto Rico. $59 \%$ on Mainland Favor State in Gallup Inc. Poll, San Juan Star, Jan. 5, 1977, at 1, col. 1 .

A bid for statehood by Puerto Rico has increasingly been viewed as inevitable. See, e.g., Puerto Rico Turnabout, Wash. Post, Aug. 20, 1977, at A14, col. 1 (editorial) (although mainland has focused little attention on issue of statehood for Puerto Rico, "question is coming"); Ramos, Has P.R. Passed The Point Of No Return? San Juan Star, Jan. 15, 1977, at 19, col. 2 ("island's economic absorption by the U.S. will inevitably result in its complete political absorption through statehood"). But see Nordheimer, Puerto Rico Is Torn by Dispute Over Seeking Statehood Status, N.Y. Times, Apr. 30, 1978, at 1, col. 4 (statehood will not receive more than simple majority in plebiscite and Congress likely to reject statehood petition). 
based resources and its ongoing economic stagnation and poverty, ${ }^{2}$ coupled with the possibility of offshore oil and mineral wealth, ${ }^{3}$ will create political pressures for Puerto Rico to demand exclusive rights to exploit its surrounding seabed ${ }^{4}$ in an area ranging from nine to 200

2. See, e.g., Hoyt, The Mineral Industry of Puerto Rico, 2 MiN. Y.B. 623, 624 (1974) (island's mineral production includes only cement, clay, lime, salt, sand and gravel, and stone); Lens, Puerto Rico could become the United States' next Vietnam, Dallas Times Herald, Aug. 14, 1977, at I-1, col. 1 \& I-8, col. 1 (discovery of copper and nickel deposits may allay but will not cure island's economic problems).

Since the increase in oil prices in 1972, the island has been beset by serious economic difficulties. See, e.g., Nordheimer, supra note I, at 56, col. I (Puerto Rico has become "'welfare state', with 63 percent of the population qualifying for Federal food stamps"); 60\% of Puerto Rican' Income Below Poverty Level, N.Y. Times, Jan. 1, 1977, at 5, col. 2 ("[u]nemployment [over 30\%], inflation and high taxes ... have seriously crippled Puerto Rico's economy").

3. Studies have shown the possibility of oil and gas deposits from two to nine miles off the northern coasts of the island. The deposits could yield an estimated 200,000 barrels of oil per day, an amount sufficient to supply the island's current daily consumption of 140,000 barrels. Letter from Michael E. Veve, Director, Legal Counsel Section of the Office of the Commonwealth of Puerto Rico (Mar. 31, 1977) (on file with Yale Law Journal). Other reports have indicated strong possibilities of limestone or dolomite off the northern coasts. Western Geophysical Company, Evaluation of Hydrocarbon Prospects of the Island of Puerto Rico, Final Report 12 (Feb. 1975) (report to Puerto Rico Water Resources Authority) (on file with Yale Law Journal). Mobil Oil Corporation has offered to explore for oil in three northern coast locations. Licha, Exploración en Tres Punlos, El Nuevo Dia, Feb. 5, 1977, at 2, col. 1. The discovery of manganese nodules, potato-shaped pellets each containing a wealth of cobalt, nickel, copper, and manganese, have reportedly been made within 200 miles of Puerto Rico's southern coast. Passalacqua Christian, Romero's miraculous fish oil-II, San Juan Star, Mar. 19, 1977, at 24, col. 1.

4. Puerto Rico might also seek rights to conserve and manage fishing in a 200 -mile economic zone, see note 116 infra (defining economic zone), off its coasts. The United States has recently declared such a zone. Fishery Conservation and Management Act of 1976, Pub. L. No. 94-265, $\$ 101,90$ Stat. 386 (codified at 16 U.S.C. $\$ 1811$ (1976)); cf. Informal Composite Negotiating Text of the Third United Nations Conference on the Law of the Sea, arts. 56, 57, U.N. Doc. A/CoNF. 62/W.P.10 (July 15, 1977) (recognizing 200-mile exclusive economic zone over living and nonliving natural resources) [hereinafter cited as Composite Text]. Although Puerto Rico's demands for rights over the seabed and over fishing management might involve a similar 200-mile limit, the two demands would involve different rights, responsibilities, and duties. Compare Convention on the Continental Shelf of the United Nations Conference on the Law of the Sea, art. 2, U.N. Doc. A/CONF. 13/L.55 (Apr. 29, 1958) (declaring rights to exploit continental shelf exclusive to coastal state) [hereinafter cited as Continental Shelf Convention] with Convention on Fishing and Conservation of the Living Resources of the High Seas of the United Nations Conference on the Law of the Sea, art. 7, U.N. Doc. A/Conf. 13/L.54 (Apr. 28, 1958) (recognizing coastal states's right to impose regulations to conserve fish but prohibiting discrimination against foreign fishermen) [hereinafter cited as Fishing Convention].

Puerto Rico would likely seek the exclusive right to explore and exploit the natural resources of the seabed. See p. 845 infra. The federal government currently authorizes the Secretary of the Interior "to grant to the highest responsible qualified bidder" leases for the exploration and development of the submerged lands under national control. See Outer Continental Shelf Lands Act of 1953, \$ 205(a), 43 U.S.C.A. \$ 1337(a) (West Supp. 1978). A payment of royalty is required. Id. $\$ 1337(\mathrm{~b})$. Similarly, Texas authorizes a School Land Board to lease to the highest bidder the exploration and exploitation rights to its submerged lands. See TEx. NAT. Res. CoDE ANN. tit. II, $\$ \$ 52.011, .019$ (Vernon 1977). Louisiana, on the other hand, authorizes its State Mineral Board to issue leases to the bidder making the "bid most advantagcous to the state." See Lu. Rev. Stat. ANn. \$ 30:127(a) (West Supp. 1978). In the Mining Law of 1975, P.R. Laws ANN. tit. 
miles into the sea. 5 The inclusion of such a provision in Puerto Rico's compact of admission could be politically necessary and practically essential. ${ }^{\circ}$

Nevertheless, because such an agreement would grant the island

28, $\S 117$ (A) (Supp, 1977), the Secretary of Natural Resources of Puerto Rico is directed to obtain from leases of submerged lands "the highest financial return possible, consistent, however, with the widest possible exploitation or extraction of the commercial mineral." This history of exploitation of submerged lands indicates that the island would follow a leasing program if it were to secure the right to explore its seabed as a state.

5. There is presently considerable disagreement about whether Puerto Rico or the United States has the right to exploit the island's seabed resources. See Puerto Rico: the oil issue, supra note 1, at 37 (United States and Puerto Rico "waging a quiet but persistent struggle ... over the island's title to offshore mineral rights"); Agrait, Puerto Rico y la Tercera Conferencia de las Naciones Unidas Sobre el Derecho Del Mar (un. published paper) (on file with Yale Law Journal) (history of island's efforts to secure rights over seabed at Third United Nations Conference on the Law of the Sea). In its Mining Law of 1975, P.R. LAws ANN. tit. 28, $\$ 111$ (Supp. 1977), the island claimed ownership of all exploitable commercial minerals in its continental shelf, which at present extend about 12 miles into the sea. Passalacqua Christian, Romero's miraculous fish oil, San Juan Star, Mar. 9, 1977, at 16, col. 1. The United States failed to recognize this claim and Puerto Rico submitted a bill to Congress, H.R. 7827, 95th Cong., 1st Sess. (1977), still in committee, seeking jurisdiction, like that exercised by Texas and Florida, over three marine leagues (nine nautical miles). Passalacqua Christian, Island "adrift in $a$ leaky canoe', San Juan Star, Mar. 6, 1978, at 15, col. 2.

Commonwealth supporters have been lobbying for Puerto Rico to claim control over the 200-mile economic zone recognized in the Composite Text, supra note 4, arts. 56, 57 . See, Bryan, Copaken Cree la Isla Esta Perdiendo Oportunidad Para Que se Establezca Limite Sobre sus Aguas Territoriales, El Mundo, Feb. 21, 1977, at 11-B, col. 5; RHC calls for pressure on U.S. to obtain rights to offshore oil, San Juan Star, July 1, 1977, at 3, col. 1.

The United States has declared its rights over the continental shelf to the limits of its exploitability. Outer Continental Shelf Lands Act of 1953, $\$ 202,43$ U.S.C.A. $\$ 1332$ (West Supp. 1978). In the Third Law of the Sea Conference, the United States proposed the recognition of a 200-mile economic zone, see note 116 infra (defining economic zone), in which coastal nations could exclusively exploit the natural resources of the seabed. Documents of the Second Committee, United States Draft Articles, 3(2) Third U.N. Conference on the Law of the Sea (Caracas, Venez.) 222, arts. 1, 2, U.N. SAles No. E.75. V.5 (Aug. 8, 1974). Thus by the time the question of statehood for Puerto Rico is faced by Congress, the United States may well recognize a 200-mile shelf zone. Therefore Puerto Rico could at a minimum ask for control to the limit of exploitability, 12 miles, and at the maximum request the 200 miles being recognized by the international community. See Composite Text, supra note 4 , art. 57 .

6. It is unlikely that opposing political parties of the island would allow statehood negotiators to concede to the federal government Puerto Rican resources as valuable as those of the seabed. See, e.g., Passalacqua Christian, supra note 3 (seabed resources have potential of "reducing and ending ... . dependence on Federal Aid Programs ... [and it] would not look good for [Governor] to be accused of giving away to the Federal Govern. ment Puerto Rico's natural resources and thus binding us over in the bondage of Federal dole forever"); RHC Calls for Pressure on U.S. to Obtain Rights to Offshore Oil, supra note 5 (former Governor calls on statehood government to demand 200-mile zone).

Seabed resources would aid Puerto Rico in solving the economic difficulties exacerbated by its mineral deficiencies, especially in oil, see note 2 supra, and may be necessary to compensate for the increased economic burdens imposed by statehood. See UNITED STATESPuerto Rico Commission on the Status of Puerto Rico, Hearings on the Status of Puerto Rico, S. Doc. No. 108, 89th Cong., 2d Sess. 593-602 (1966) (Dr. Alvin Mayne) (statehood would require greater contribution to federal purse, and labor costs would increase prohibitively if federal minimum wage laws applied to island). But see id. at 623-35 (Arthur Burns) (statehood for Puerto Rico is economically feasible). 
seabed rights denied to any of the fifty states at their admission to the Union, ${ }^{7}$ it would probably meet with opposition based on the "equal footing doctrine." 8 That doctrine "prevents extension of the sovereignty of a State into a domain of political and sovereign power of the United States from which the other States have been excluded" when the state enters the Union..$^{9}$ Although the Supreme Court in Alabama v. Texas ${ }^{10}$ held that Congress has the power under the property clause of the Constitution to grant existing states unequal seabed rights, ${ }^{11}$

7. See pp. 832.33 infra (discussing United States v. Texas, 339 U.S. 707 (1950), which vested seabed rights in federal government at state's admission because of equal footing doctrine).

8. See note 9 infra.

Another objection involves a possibility that the Puerto Rican government might seek to favor its citizens in granting rights to exploit the seabed. See Mining Law of 1975, P.R. LAws ANN. tit. 28, $\S 117(14)$ (Supp. 1977) (requiring every person who leases right to extract commercial minerals to agree that "insofar as economically possible, persons residing in Puerto Rico be employed for the works originating and carried out under such lease, and that such persons be trained in such operations as require technical skills"). Puerto Rico as a state, however, would be subject to challenges of such actions based on the privileges-and-immunities and equal protection clauses. U.S. ConST. amend. XIV, § 1; see, e.g., Toomer v. Witsell, 334 U.S. 385, 395-403 (1948) (South Carolina licensing scheme discriminating against nonresident fishermen deciared invalid under privileges-and-immunities clause); Alexandria Scrap Corp. v. Hughes, 391 F. Supp. 46, 56-58 (D. Md. 1975) (Maryland statute requiring processors to have office in state contrary to equal protection clause). It is beyond the scope of this Note to discuss the propriety of such favoritism by a state toward its own citizens.

9. United States v. Texas, 339 U.S. 707, $719-20$ (1950) (plurality opinion). The equal footing requirement first appeared in the Northwest Ordinance of 1787, see 1 THE Documentary History of the Ratification of the Constitution 168 (M. Jensen ed. 1976) (quoting Ordinance in full), as a condition demanded by Virginia for its cession of western lands to the Union, see Hanna, Equal Footing in the Admission of States, 3 BAYLoR L. REv. 519, 523 (I951) (history of equal footing clause). Beginning with the admission of Tennessee in 1796, all states were admitted using the equal footing clause. Id.

Congressional concern and belief in the necessity for "equality" of states was quite evident when Hawaii attempted, during its statehood negotiations, to secure control over the seabed between its islands and was rebuffed by equal footing arguments. See Statehood for Hawaii: Hearings on S. 49, S. $51 \&$ H.R. 3575 Before the Senate Comm. on Interior and Insular Affairs, 83d Cong., 1st \& 2d Sess. pt. 2, at 40.53 (1954) (history of Hawaii's demands and their resolution). Hawaii finally agreed to accept a condition in its act of admission that the Submerged Lands Act of 1953 "shall be applicable to the State of Hawaii, and the said State shall have the same rights as do existing states thereunder." Id. pt. 3, at 725 .

It seems probable that similar equal footing arguments will arise during Puerto Rico's negotiations over statehood because it is so often assumed that entering the Union would automatically require relinquishment to the federal government by the island of its rights to seabed resources. See, e.g., O'Toole, Offshore Oil Issue Raised in P.R. Proposal, Wash. Post, Jan. 2, 1977, at A2, col. 3 (President Ford's statehood proposal may have been motivated by desire to federalize island's offshore resources); Passalacqua Christian, supra note 3 (island's rights over seabed would disappear if it became state; under statehood it would be entitled to only. three miles under United States laws). Finally, precedent indicates that opposition by existing states or the executive might arise if the island were granted disproportionate rights. See notes 101 \& 102 infra.

10. 347 U.S. 272 (1954) (per curiam).

11. Id. at 273; see U.S. Consr. art. IV, $\S 3, \mathrm{cl} .2$ ("The Congress shall have Power to dispose of and make all needful Rules and Regulations respecting the Territory or other Property belonging to the United States ....") 
the Court has not directly addressed the question whether the equal footing doctrine permits Congress to grant rights to an incoming state that exceed those granted to any existing state at its admission. ${ }^{12}$

This Note suggests a new historical analysis of the equal footing doctrine that demonstrates that the doctrine poses no barrier to such an extensive seabed grant upon Puerto Rico's admission into the Union. The Note defines the submerged lands issues left unsettled by the case law, and derives a framework for the equal footing doctrine from a historical analysis of submerged lands and equal footing cases. It then applies this framework to Puerto Rico's claims and demonstrates that Congress may, without violating the equal footing doctrine, cede seabed rights to the island on admission. ${ }^{13}$ Finally, the Note suggests considerations for the language of such an agreement and defines its limitations.

\section{The Allocation of Seabed Rights}

In a long line of cases, ${ }^{14}$ the Supreme Court has invoked the equal footing doctrine to vest control over the seabed in the federal government. ${ }^{15}$ Although their reasoning and results have been subjected to numerous criticisms, ${ }^{16}$ the cases retain their precedential value. ${ }^{17}$ The

12. See pp. 832-33, 838 infra.

A mere expectancy or even a promise of seabed control after admission would not be a sufficient guarantee for Puerto Rico as it commits itself to the irrevocable status of statehood. Seabed rights are inextricably tied to the other economic and political issues surrounding Puerto Rican statehood. See note 6 supra. The grant of seabed rights must be simultaneous with admission. See Passalacqua Christian, supra note 3 (admission to Union without full seabed rights would be "cruel jest" on Puerto Rican people).

13. The present Governor of Puerto Rico, Carlos Romero Barcelo, has declared that if his party is returned to power in 1980 , he will pursue a plebiscite for statehood the next year. NEwswEEk, Sept. 11, 1978, at 35. In order to make an objective and informed decision concerning their future, the Puerto Rican people need to understand the difference between the constitutional and the political prices that statehood would require. The equal footing framework developed in this Note can be applied to test the constitutional basis of any condition for admission demanded by Congress or by Puerto Rico.

14. See, e.g., United States v. Texas, 339 U.S. 707 (1950); United States v. Louisiana, 339 U.S. 699 (1950); United States v. California, 332 U.S. 19 (1947).

15. See pp. $831-33$ infra.

16. See, e.g., Hanna, The Submerged Land Cases, 3 BAYLoR L. REv. 201, 204 (1951) ("few judicial decisions . . . contrary to the expressed views of more well-informed lawyers"); Naujoks, Title to Lands Under Navigable Waters, 32 MARQ. L. REv. 7, 37 (1948) ("United States Supreme Court is wrong . . . in holding that the Federal Government has paramount rights to the tidelands"). But see Clark, National Sovereignty and Dominion Over Lands Underlying the Ocean, 27 Tex. L. REv. 140, 141 (1948) ("historical, political and practical" reasons exist for federal dominion over seabed).

17. See United States v. Maine, 420 U.S. 515, 519, 524 (1975) (reaffirming reasoning and results of cases vesting rights over seabed in federal government). A Special Master appointed by the Court to take and review evidence in Maine found that the historical conclusions of the submerged lands cases were correct. Report of Albert B. Maris, Special Master, at 75-81, United States v. Maine, 420 U.S. 515 (1975) [hereinafter cited as Special Master's Report]. The Court in Maine accepted the Master's findings. 420 U.S. at 522-25. 
cases merit careful analysis, because the Court has never explicitly decided whether the equal footing doctrine is a constitutional limitation on the power of Congress to set the terms for admission into the Union and, if so, whether this limitation precludes Congress from granting disproportionate seabed rights to an incoming state.

Until the 1940s, the leading authority concerning states' rights to control over the seabed was the 1845 case of Pollard's Lessee v. Hagan. ${ }^{18}$ Pollard held that because Alabama had been admitted to the Union on an "equal footing" with the other states, it was entitled to the same rights of sovereignty and jurisdiction over shorelands as were possessed by the original states. ${ }^{19}$ For over a century Pollard stood for the broad proposition that states owned title to all "navigable waters, and the soils under them" ${ }^{20}$ within their historic boundaries. ${ }^{21} \mathrm{~A}$ series of Supreme Court decisions from 1947 to 1950, the Tidelands Cases, ${ }^{22}$

18. 44 U.S. (3 How.) 212 (1845). In Pollard, the Court rejected plaintiff's claim to certain shorelands based on a federal patent issued after Alabama's admission into the Union. Plaintiff had argued that the United States in Alabama's compact of admission retained ownership of the lands. Id. at 220-21.

19. Id. at 228-29. The Court held that, at the time of the American Revolution, "the people of each state became themselves sovereign," and possessed the absolute right to all navigable waters and soils within the colony. Id. at 229 (quoting Martin v. Waddell, 41 U.S. (16 Pet.) 367, 410 (1842)). The independent colonies retained this sovereign right at the formation of the Union. Id.

The Court in Pollard also invoked the premise that the federal government could not permanently hold or condemn lands within the boundaries of a state without the state's express consent. $I d$. at 223 . The Constitution reserved title to "shores of navigable waters, and the soils under them" to the original states. $I d$. at 230. Alabama was admitted on an equal footing, because the Court imputed to the state at the time of its admission ownership of and sovereignty over all lands that it did not explicitly cede to the federal government in its compact of admission. Id. at 223. The Court found that a provision reserving for the United States waste and unappropriated lands (public lands) did not include shorelands, and that a condition concerning freedom of navigable waters was only a "regulation of commerce" and did not confer property rights on the United States. $I d$. at 230 . Therefore, the federal patent to plaintiff was invalid. $I d$.

It was not until 1875, in Kohl v. United States, 91 U.S. 367 (1875), that the Supreme Court held that the power of eminent domain was inherent in sovereignty and that, consequently, in order to implement its constitutional functions, the United States could condemn lands within a state without the state's consent. Id. at 373-74. In United States v. Texas, 339 U.S. 707 (1950), the Court plurality further held that an express state grant at admission was not necessary in order for a state to relinquish title to the United States. Id. at 718.

20. 44 U.S. (3 How.) at 230.

21. Pollard actually held that states owned title to all "shores of navigable waters, and the soils under them." Id. (emphasis added). Nevertheless, subsequent cases interpreted Pollard to mean that a state owned title to all tide waters and their beds within the state's territorial boundaries. See, e.g., The Abby Dodge, 223 U.S. 166, 175 (1912); McCready v. Virginia, 94 U.S. 391, $394-95$ (1876). For a general history of cases relying on the Pollard rule, see Naujoks, supra note 16, at 21-37.

22. "Tidelands" is a misnomer given to three submerged lands cases-United States v. Texas, 339 U.S. 707 (1950), United States v. Louisiana, 339 U.S. 699 (1950), and United States v. California, 332 U.S. 19 (1947). See Hyder, United States v. California, 19 Miss. L.J. 265, 265 \& nn.2-3 (1948) (Tidelands Cases involved lands under tide waters and not tidelands, lands covered and uncovered by ordinary tide). 
overturned this broad reading of Pollard, but failed to provide a consistent or clear framework for evaluating subsequent equal footing claims.

In the first Tidelands Case, United States v. California, ${ }^{23}$ the Court upheld the federal government's claim to all submerged land rights in the three-mile marginal sea ${ }^{24}$ claimed by California. ${ }^{25}$ Because the original states had never acquired imperium (regulatory porver) or dominium (ownership interest) ${ }^{26}$ over the submerged lands of the marginal sea, and because California was admitted to the Union on an equal footing with the original states, the Court held that California had demonstrated no ownership of the claimed area. ${ }^{27}$ Pollard was distinguished by the fact that acquisition, protection, and control of the three-mile marginal belt "has been and is a function of national external sovereignty." 28 Thus, lands in which "national interests" such as defense, commerce, and foreign affairs were dominant were deemed

23. 332 U.S. 19 (1947).

24. "Marginal sea" and "territorial sea" refer to the three-mile belt of water measured from the seaward edge of inland waters. See United States v. Louisiana, 394 U.S. 11, 22 (1969) (defining terms); Manchester v. Massachusetts, 139 U.S. 240, 258 (1891) (recognizing one league as minimum limit).

25. 332 U.S. at $34-36,39-40$. California argued that because the original states acquired title to the three-mile belt from the English Crown and because it had been admitted on an equal footing with the original states, it acceded to the same right of title over the submerged lands. Id. at 23. California also pleaded several defenses all of which the Court dismissed summarily. Id. at 23-24 \& n.2, 39-40.

26. The California majority held that national interests required that the federal government have the "powers of dominion and regulation" over the marginal belt. Id. at 35. Justice Frankfurter, in dissent, used the terms "dominium" and "imperium," $i d$. at 43-44, to refer to what the majority labelled "dominion" and "regulation." He argued that although the majority was right in denying California a proprietary interest or dominium over submerged lands and in asserting that national interests conferred regulatory power on the federal government, the majority failed to explain how the federal government acquired dominium. Id. at 44. Justice Frankfurter's "imperium" and "dominium" terminology was later adopted by the plurality in United States v. Texas, 339 U.S. 707, 712-13 (1950).

27. 332 U.S. at $32,38-39$. Without an evidentiary hearing, the Court said that it could not conclude that "the thirteen original colonies separately acquired ownership of the three-mile belt or the soil under it, even if they did acquire elements of the sovereignty of the English Crown by their revolution against it." Id. at 31 (footnote omitted). In United States v. Maine, 420 U.S. 515 (1975), a Special Master finally conducted a hearing on historical evidence, see Special Master's Report, supra note 17, at 25-65, and the Court explicitly found that the colonies had not owned the three-mile belt. 420 U.S. at 522 . But see Hardwicke, Illig \& Patterson, The Constitution and the Continental Shelf, 26 Tex. L. Rev. 398, 408-26 (1948) (colonies and original states were landowners of submerged lands).

28. 332 U.S. at 34 . The Court limited the Pollard rule to cover only state ownership of inland waters and soils under them (land between the lines of the ordinary high and low water marks). Id. at 36 . The Pollard rule had been applied in other cases involving the marginal sea. See note 21 supra (citing cases). The California Court read those cases as involving only the right of states to regulate fishing in the absence of conflicting congressional legislation. 332 U.S. at 37-38. 
to be within the "paramount rights" and powers of the federal government after the admission of a state into the Union. ${ }^{20}$

Three years later, the Court followed California "a fortiori" in United States $v$. Louisiana, ${ }^{30}$ and expanded its reasoning in United States $v$. Texas. ${ }^{31}$ Texas, as an independent republic, had claimed and exercised both imperium and dominium over submerged lands three marine leagues (nine nautical miles) from its shore. ${ }^{32}$ Texas argued that at its admission it ceded to the United States only imperium, and not dominium, to this area. ${ }^{33}$ Justice Douglas, writing for the Court plurality, disagreed, holding that "although dominium and imperium are normally separable and separate," 34 "national interests and national responsibilities" compelled federal control of both regulatory and property interests in the seabed. ${ }^{35}$ Because it entered the Union on an equal footing with the original states, ${ }^{36}$ Texas automatically lost all

29. 332 U.S. at $34-36,38-39$.

30. 339 U.S. 699,705 (1950). Based on a 1938 state statute, Louisiana claimed control over the seabed within 27 miles of its shores. Id. at 703. The United States sought a declaration of its rights to the area. Id. at 701. The Court held that the federal government's sovereignty extended to the entire area claimed by Louisiana, even though no federal claim to the seabed beyond three miles had been proven. Id. at 704-05. The Truman Proclamation of 1945, Excc. Proclamation No. 2667, 3 C.F.R. 67, 68 (1945), had declared United States "jurisdiction and control" over the continental shelf, but, as was explained in an accompanying relcase, Exec. Order No. 9633, 3 C.F.R. 437 (19.45), the Truman Proclamation did not purport to vest title to the shelf in either the federal or state governments. But see Note, Conflicting State and Federal Claims of Title in Submerged Lands of the Continental Shelf, 56 YALE L.J. 356, 369 (1947) (Supreme Court could use Truman Proclamation to vest title to shelf in federal government). It was not until three years after Louisiana that Congress declared it "to be the policy of the United States that the subsoil and seabed of the [shelf area outside the marginal sea] appertain to the United States." Outer Continental Shelf Lands Act of 1953, Pub. L. No. 83.212, $\S 3,67$ Stat. 462 (codified at 43 U.S.C.A. $\$ 1332$ (West Supp. 1978)). Once again, as in United States v. California, 392 U.S. 19 (1947), the Court in Louisiana failed to explain how the federal government acquired dominium over the shelf. See note 26 supra (discussing California Court's failure to explain national acquisition of dominium).

31. 339 U.S. 707 (1950) (plurality opinion). The United States in Texas sought a declaration of rights over the submerged lands in the Gulf of Mexico bordering Texas. Id. at 709 .

32. Id. at 712-13. The Court plurality assumed the validity of Texas's claim that it had exercised imperium and dominium over the three marine league belt as a Republic. Id. at 717 .

33. Id. at 712-13. The intention to cede only imperium, Texas argued, was evidenced by the retention of vacant and unappropriated lands in its compact of admission. Id. at 714-15; see Joint Resolution for annexing Texas to the United States, J. Res. 8, 28th Cong., 2d Sess. 797 (1845). The United States responded by arguing that Texas's grant of all property necessary to the public defense impliedly ceded the marginal belt to the federal government. 339 U.S. at 714-15.

34. 339 U.S. at 719 (footnote omitted).

35. Id.

36. Justice Douglas found the equal footing doctrine to control and bind the substance of admission even without the agreement of the state to the terms of the admission declaration. The Justice relied on the equal footing clause of the Joint Resolution for annexing Texas to the United States, J. Res. 8, 28th Cong., 2d Sess. 797 (1845), to dispose 


\section{Puerto Rican Seabed Rights}

seabed dominium to the federal government. ${ }^{37}$

In 1953, Congress passed the Submerged Lands Act, ${ }^{38}$ which vested ownership of the marginal sea and its resources in the states ${ }^{39}$ and provided that states could claim a greater seaward boundary to a limit of three marine leagues in the Gulf of Mexico" if "it was so provided by its constitution or laws prior to or at the time such State became a member of the Union, or if it has been heretofore approved by Congress." 41 In a per curiam decision in Alabama v. Texas, ${ }^{42}$ the Court denied the motions of Alabama and Rhode Island for leave to file complaints challenging the constitutionality of the Submerged Lands Act. ${ }^{43}$ Alabama and Rhode Island claimed that by granting some Gulf states an extended boundary over the three miles to the three marine league limit, the Submerged Lands Act violated the equal footing guarantees in their acts of admission and resulted in their "inferior sovereignty." 44

The Court, which included only three members of the majority that had decided the Tidelands Cases, summarily upheld the Submerged Lands Act on the ground that Congress, under the property clause of

of the controversy. 339 U.S. at 719. Texas, however, was not admitted under that "Joint Resolution" but under the Joint Resolution for the Admission of Texas into the Union, J. Res. 1, 29th Cong., 1st Sess. 108 (1845). The latter resolution was never "submitted to nor accepted by Texas." Hanna, supra note 9, at 520. The Court plurality later ordered the amendment of the Texas opinion to make correct reference to the proper document. United States v. Texas, 340 U.S. 848 (1950).

37. 339 U.S. at 718.

38. Pub. L. No. 83-31, 67 Stat. 29 (1953) (codified at 43 U.S.C. $\$ \S 1301-1315$ (1970)). The Act was intended to undo the effects of the Tidelands triad. See S. REP. No. 133, 83d Cong., 1st Sess. 8, reprinted in [1953] U.S. Code CoNg. \& Ad. News 1474, 1481 ("purpose of [Submerged Lands Act] to write the law ... as the Supreme Court believed it to be in the past-that the States shall own . . . all lands under navigable waters within their territorial jurisdiction"); H.R. REP. No. 695, 82d Cong., Ist Sess. 5, reprinted in [1953] U.S. Code Conc. \& AD. News 1395, 1399 (Submerged Lands Act fixed as law that which prior to Califormia "believed and accepted to be the law of the land"-that states own submerged lands within their boundaries). The Supreme Court viewed the Act as an exercise of Congress's power to dispose of public property, and not as a mandate to overturn the Tidelands Cases. See United States v. Louisiana, 363 U.S. 1, 7 (1960).

39. 43 U.S.C. $\$ 1311$ (a) (1970).

40. Id. $\S 1301$ (b) ("in no event shall the term 'boundaries' . . . be interpreted as extending from the coast line more than three geographical miles into the Atlantic Ocean or the Pacific Ocean, or more than three marine leagues into the Gulf of Mexico").

41. Id. $\$ 1312$.

42. 347 U.S. 272 (1954).

43. Id. at 273.

44. Complainant Alabama's Brief in Support of Motion for Leave to File Complaint and Complaint at 57.72, Alabama v. Texas, 347 U.S. 272 (1954) (Alabama grant extends only to three-mile belt; any greater grant to other states denies equal footing and results in making Alabama's sorereignty inferior); Brief for Complainant Rhode Island at 10, Alabama v. Texas, 347 U.S. 272 (1954) (Rhode Island claims Submerged Lands Act violates equal footing clause). 
the Constitution, could divest itself of the "public domain." Douglas, the author of Louisiana and Texas, and Justice Black, the author of California, relied on the equal footing doctrine to argue that Congress had no authority to "relinquish elements of national sovereignty over the Oceans." 46 The new Court in Alabama, however, overturned Texas sub silentio by holding that Congress in a postadmission grant could separate property interests in the seabed from national sovereignty. ${ }^{47}$ The Court subsequently confirmed Congress's power to cede federal "property" to states in unequal portions. ${ }^{48}$ Recently, in United States $v$. Maine ${ }^{49}$ the Court reaffirmed the results of its Tidelands Cases by upholding the paramount rights of the federal government to the continental shelf ${ }^{50}$ outside the marginal sea. ${ }^{51}$ Thus it re-

45. 347 U.S. at 273.

46. Id. at 279 (Black, J., dissenting); see id. at 282 (Douglas, J., dissenting). Justice Douglas viewed federal powers over submerged lands as "incidents of national sovereignty" that could not be "abdicated" without undermining the equality of states the equal footing clause required. Id. at 282-83.

47. See 34 B.U. L. REv. 504, 507 (1954) (Alabama "tacitly repudiated" Texas); cf. 30 U. Miam L. Rev. 203, 213 (1975) (Submerged Lands Act, granting seabed rights to states, is "de facto repudiation" of prior rationale for vesting control in federal government). Texas and Alabama indicate that the Court perceived a difference between a grant at admission and a grant after admission. The Texas plurality viewed seabed rights as so intertwined with sovereignty as to be inseparable at admission. Otherwise "there is or may be in practical effect a subtraction in favor of Texas from the national sovereignty of the United States." 339 U.S. at 719. A seabed grant after admission, however, "was merely an exercise of" paramount national power. United States v. Maine, 420 U.S. 515, 524 (1975). This reasoning fails to explain the argument in Texas that in the case of seabed rights, property rights (dominium) follow and commingle with sovereignty (imperium). 339 U.S. at 719. In effect, the underpinning of Texas was overturned because in Alabama the Court found property rights separate and separable from national sovereignty. But cf. p. 840 infra (harmonizing results of Alabama and Texas).

48. In United States v. Louisiana, 363 U.S. 1 (1960), and United States v. Florida, 363 U.S. 121 (1960), the Court recognized claims under the Submerged Lands Act by Texas and Florida for dominium over three marine leagues in the Gulf of Mexico, but denied similar claims by Louisiana, Mississippi, and Alabama. Texas and Florida showed that it was the intention of Congress to recognize the extended boundaries that existed at the time of Texas's admission to the Union and at the time of Florida's readmission after the Civil War. This showing of congressional intent was the sole element necessary to establish entitlement under the Submerged Lands Act. United States v. Louisiana, 363 U.S. $1,29-30$ (1960).

49. 420 U.S. 515 (1975). The defendants in Maine were the 13 states bordering the Atlantic Ocean. Id. at 516-17.

50. Continental shelves have typically been defined

as those slightly submerged portions of the continents that surround all the continental ... mass that forms the lands above water. They are that part of the continent temporarily (measured in geological time) overlapped by the oceans. The outer boundary of each shelf is marked by a sharp increase in the slope of the sea floor. It is the point where the continental mass drops off steeply toward the ocean deeps.

H.R. ReP. No. 215, 83d Cong., Ist Sess. 6, reprinted in [1953] U.S. Code CoNG. \& AD. NEWS 1385, 1390.

51. 420 U.S. at 527-28. 
mains unclear whether the equal footing doctrine is a constitutional bar to a congressional grant of disproportionate seabed rights to an incoming state. In light of subsequent cases, it cannot be argued that the Texas decision settled this question.

\section{The Equal Footing Doctrine: A Historical Reinterpretation}

One reason the submerged lands cases seem confused or inconsistent is that the Court has never adequately defined the content or sources of the equal footing doctrine. The equal footing doctrine ultimately rests on concepts of federalism: the United States is a "union of political equals." ${ }^{2}$ Although superficially derived from a clause common in statehood compacts, ${ }^{53}$ equal footing in this century has emerged as an amalgam of constitutional and statutory precepts. Constitutional principles alone act as an affirmative limitation on congressional power to negotiate terms in compacts of admission, but statutory precepts also guide courts as they interpret such compacts.

\section{A. The Constitutional Component of the Equal Footing Doctrine}

The Constitution provides that "[n]ew States may be admitted by the Congress into this Union." 54 Congress may, on "penalty of denying admission," require any conditions for entry into the Union. ${ }^{55}$ Since the admission of Ohio in $1802,{ }^{56}$ Congress has imposed on states a variety of special conditions that have limited the sovereign and political powers that states can exercise after admission. ${ }^{57}$ On the other

52. Case v. Toftus, 39 F. 730, 732 (C.C.D. Or. 1889) ("The doctrine that new states must be admitted ... on an 'equal footing' with the old ones does not rest on any express provision of the constitution ... but on what is considered ... to be the general character and purpose of the union of the states . . . -a union of political equals.")

53. See p. 836 infra.

54. U.S. Const. art. IV, $\$ 3$, cl. 1. See generally Park, Admission of States and the Declaration of Independence, 33 TEMP. L.Q. 403, 405 (1960) (five procedural methods by which states have historically been admitted).

55. Coyle v. Smith, 221 U.S. 559, 568 (1911); cf. Brittle v. People, 2 Neb. 198, 216 (1872) (how states will be admitted is political question to be settled by territorial residents and Congress-not courts).

56. See Enabling Act of Ohio, ch. 40, 2 Stat. 173 (1802). Prior to Ohio's admission, Vermont, Kentucky, and Tennessee, the first three states added to the new union, were admitted without the imposition of conditions. See An Act for the admission of Tennessee, ch. 47, I Stat. 491 (1796); An Act for the admission of Vermont, ch. 7, 1 Stat. 191 (1791); An Act admitting Kentucky, ch. 4, I Stat. 189 (1791). For an explanation of enabling acts and acts of admission, see Park, supra note 54, at 405 (enabling act authorizes constitutional convention whereas act of admission ratifies admission of state; act of admission need not be preceded by enabling act).

57. See note 60 infra (examples of conditions); Dunning, Are the States Equal Under the Constitution? 3 Polmrcal ScI. Q. 425 (1888) (conditions imposed on incoming states in nineteenth century); Park, supra note 54, at 406-10 (conditions imposed in twentieth century). 
hand, since the admission of Tennessee in 1796,58 Congress has included in each state's act of admission a clause providing that the state would enter the Union "on an equal footing with the original States in all respects whatever." " footing" clauses and the conditions limiting the sovereign and political powers of particular states after admission, ${ }^{60}$ the Supreme Court in the nineteenth and early twentieth centuries held the conditions to be either valid exercises of Congress's commerce or property powers ${ }^{\mathbf{0 1}}$ or state constitutional provisions that could later be removed by the amendment process. ${ }^{62}$

Nevertheless, the Supreme Court struck down one such condition in 1911 in Coyle v. Smith.$^{63}$ The Court in Coyle upheld an Oklahoma statute moving the state capital from Guthrie to Oklahoma City against a challenge that the move violated the state's enabling act. Plaintiff, a property owner in Guthrie, claimed that the statute contravened a condition in the act under which the state had agreed not to move its

58. See An Act for the admission of Tennessee, ch. 47, 1 Stat. 491 (1796).

59. See Hanna, supra note 9, at 523-24. Prior to Tennessee's admission, Vermont and Kentucky were each "received and admitted into this Union, as a new and entire member of the United States of America." An Act for the Admission of Vermont, ch. 7, 1 Stat. 191 (1791); An Act Admitting Kentucky, ch. 4, 1 Stat. 189 (1791). This language is close to the equal footing terminology, although the phrase is not used explicitly.

60. In reviewing the conditions imposed on states, one nineteenth century scholar suggested that "the theory that all states have equal powers must be regarded as finally defunct." Dunning, supra note 57, at 452. Many of the conditions commonly imposed upon incoming states, such as the duties to keep navigable rivers toll-free for United States citizens and tax nonresident and resident proprietors equally, see, e.g., Enabling Act of Louisiana, ch. 21, $\$ 3,2$ Stat. 641 (1811), were grounded in Congress's constitutional powers. Other less common conditions, such as requirements that state constitutions provide that government officials be literate in English, see, e.g., Enabling Act of New Mexico and Arizona, Pub. L. No. 61-219, § 2, 20, 36 Stat. 557 (1910), or that polygamous marriages be prohibited, see, e.g., Enabling Act of Utah, ch. 138, \$ 3, 28 Stat. 107 (1894), did not involve matters that were generally viewed at that time as subject to federal regulation. See C. Beard, American Government and Politics 459-72 (4th ed. 1926) (states in eighteenth and nineteenth century differed widely in self-imposed electoral requircments); G. Curtis, Admission of Utah: Limitation of State Sovereignty by Compact with the United States 17 (1887) (opinion pamphlet) (Constitution reserved to states power to control domestic relations, including polygamy; Utah's power limited because of terms of compact of admission).

61. U.S. Const. art. I, $\$ 8$, cl. 3 (commerce clause); id. art. IV, $\S 3$, cl. 2 (property clause); see, e.g., United States v. Sandoval, 231 U.S. 28, 38 (1913) (conditions relating to regulation of affairs with Indian tribes within commerce power clause); Stearns v. Minnesota, 179 U.S. 223, 250 (1900) (provisions relating to federal property within power to dispose of property).

62. Coyle v. Smith, 221 U.S. 559, 568 (1911) (dictum); accord, Brittle v. People, 2 Neb. 198, 218 (1872); see Monnet, Violations by a State of the Conditions of its Enabling Act, 10 Colum. L. REv. 591, 605 (1910) (Congress cannot "keep a State in tutelage after it comes into the Union"; state can always amend its constitution).

63. 221 U.S. 559 (1911). 
capital before $1913 . .^{64}$ The Court held that under the equal footing doctrine Congress cannot, as a condition of admission, either place limitations on the powers of a new state or demand the right to exercise powers over a new state not authorized by the Constitution. ${ }^{65}$ The Court suggested for the first time that the equal footing doctrine derived its force not merely from the inclusion of an equal footing clause in acts of admission, but also from the constitutional imperative of equality among the states. ${ }^{66}$ It asserted that the words "this Union" in Article IV of the Constitution"i refer to "a union of States, equal in power, dignity and authority, each competent to exert that residuum of sovereignty not delegated to the United States by the Constitution itself." 68

The holding in Coyle rested on notions of "dual federalism." Under this doctrine federal and state governments were viewed as fully independent in their respective spheres of power, with federal powers enumerated by Article I and all other powers reserved to the states by the Tenth Amendment. ${ }^{69}$ As a result, Congress cannot in an act of admission diminish or impair the sovereign and political powers of an incoming state, including the power to designate its capital..$^{0}$

64. Id. at 563-64; see Enabling Act of Oklahoma, Pub. L. No. 59-234, § 2, 34 Stat. 267 (1906). The condition was not included in the state's constitution but was adopted in a separate ordinance. 221 U.S. at 564-65.

65. 221 U.S. at 573.

66. Id. at 580 .

67. U.S. Consr. art. IV, $\S 3, \mathrm{cl} .1$ ("New States may be admitted by the Congress into this Union ....")

68. 221 U.S. at 567.

69. The term "dual federalism" was coined by Professor Corwin. See E. Corwin, Tre Twilight of The Supreme Court I (1934). He used the term to describe the judicial approach to federalism that prevailed from the Taney Court to the New Deal. Id. at 50 .

Many of the Supreme Court's decisions before the New Deal reflected dual federalist notions. See, e.g., United States v. Butler, 297 U.S. 1, 77-78 (1936) (Agricultural Adjustment Act unconstitutional because taxing power cannot be used for federal regulation in area reserved to states); Hammer v. Dagenhart, 247 U.S. 251, $273-76$ (1918), overruled, United States v. Darby, 312 U.S. 100, 116 (1941) (Act of 1916 to prevent interstate commerce in products of child labor unconstitutional as federal intrusion into state matters). See generally M. Vile, The Structure of American Federalism 68 (1961) (under dual federalism, exercise of federal government's constitutional powers limited by state sovereignty; Tenth Amendment frequently invoked to curtail express congressional power); Corwin, The Passing of Dual Federalism, 36 VA. L. Rev. 1, 4 (1950) (federal and state governments are co-ordinate with and equal to one another).

70. 221 U.S. at $\mathbf{5 7 3}$ (sovereign and political powers of incoming states cannot be "constitutionally diminished, impaired or shorn away by any conditions, compacts or stipulations" in acts of admission).

The equal footing doctrine, however, does not require the equality of states in the manner in which they exercise sovereign and political powers. For example, in such matters as powers delegated to the three branches of government or to local governments, the arrangements of the states vary substantially. Compare CaL. Const. arts. IV, V (delegating general powers to autonomous executive branch; relying extensively on ref- 
Conversely, the equal footing doctrine, based on notions of sovereign equality, might also prohibit the enlargement of the powers of particular states into areas granted by the Constitution to the national government. This inversion of the constitutional equal footing doctrine formed the basis for the Court's 1950 plurality decision in United States v. Texas. ${ }^{71}$ Although it did not explicitly hold that Congress could not expand the sovereign and political powers of an incoming state in a compact of admission, the Court plurality cited constitutional reasons as preventing "any implied, special limitation of any of the paramount powers of the United States in favor of a State." 72

Since 1937, the doctrine of dual federalism has been replaced by theories of "cooperative federalism." Under cooperative federalism, federal and state governments are viewed as sharing powers and functions, although national powers and interests take precedence over state sovereignty ${ }^{73}$ Consistent with this more expansive view of federal sovereignty, the plurality opinion in Texas suggested that the equal footing doctrine "prevents extension of the sovereignty of a State" into an area of paramount rights of the United States "from which the other States have been excluded, just as it prevents a contraction of sovereignty ... which would produce inequality among the States."it

erenda) with LA. CoNsT. arts. III-VI (containing specific and detailed delimitation of powers, duties, and organization of three branches and of local governments). Additionally, the courts have historically validated congressional power to control the formation and content of constitutions of states entering the Union. As a result, states differ in the sovereign and political powers they exercised at admission. See p. 835 supra. The equal footing doctrine permits each state after admission to choose to exercise the same degree of sovereign and political powers as every other state. Cf. Case v. Toftus, $39 \mathrm{~F}$. 730, 732 (C.C.D. Or. 1889) ("true constitutional equality between the states . . extends to the right of each ... to have and enjoy the same measure of local or self government").

71. 339 U.S. 707, 719-20 (1950); see Frost, Judicial Expansion of Seaward Boundaries Above Submerged Lands, 16 N.Y.U. INTRA. L. Rev. 235, 242 (1961) (Texas plurality used concept of " "converse equal footing" ").

72. 339 U.S. at 717; see id. at 718 (United States responsibilities with respect to "foreign commerce, the waging of war, the making of treaties, defense of the shores, and the like" compel conclusion that United States's supremacy over seabed must be unabridged).

73. See Corwin, supra note 69 , at 21 ("cooperative conception of the federal relationship"). Cases after 1937 have reflected the cooperative federalist notions. See, e.g., Fry v. United States, 421 U.S. 542, 547-48 (1975) (interference with state affairs by application of Economic Stabilization Act to state employees upheld as within rational congressional exercise of power); United States v. Darby, 312 U.S. 100, 124 (1941) (Fair Labor Standards Act upheld even though it affected state sovereignty; national government can "resort to all means for the exercise of a granted power"). See generally M. ReaGan, The New Federalism 21-23 (1972) (constitutional revolution of 1937 began view of federal and state cooperation in "running programs" and in "passing statutes," as state powers no longer held to impede or limit national powers). The Court has, nevertheless, recently moved to limit notions of cooperative federalism. See National League of Cities v. Usery, 426 U.S. 833 (1976) (Tenth Amendment affirmative limit on commerce power when legislation infringes on state sovereignty).

74. 339 U.S. at 719-20 (citation omitted). 
The Texas plurality, however, returned to a model of dual federalism by assuming that exclusive federal control over the seabed was necessary. ${ }^{\mathrm{T}}$

The Court in Alabama v. Texas ${ }^{76}$ was misguided in not addressing the constitutional equal footing arguments. ${ }^{77}$ The reasoning in Texas required the Alabama Court to determine whether the Submerged Lands Act undermined the constitutional "equality of States" so as to make them " 'different in [the] dignity and power'" that they share as co-equal members of the Union. ${ }^{78}$ Because the Alabama Court did not consider the constitutional language in Texas, the latter opinion should not be understood to bar affirmative congressional actions that vest seabed rights in some states that are greater than those enjoyed by other states. ${ }^{79}$

\section{B. The Statutory Component of the Equal Footing Doctrine}

Ultimately, the holding in United States $v$. Texas ${ }^{80}$ must be viewed as turning on statutory, not constitutional interpretation. Although the Constitution guarantees sovereign equality to the states, it does not ensure their economic or proprietary equality. Because state sovereignty includes the right to acquire and to dispose of property, ${ }^{81}$ and because the Constitution gives Congress plenary power to grant federal lands to the state, ${ }^{82}$ equality either in size or in percentage of public lands held among the states would be unrealistic. ${ }^{83}$ Acts of admission,

75. Under dual federalism, federal and state governments were viewed as co-equals, supreme in their independent spheres. See p. 837 supra. The plurality, by coalescing imperium and dominium, returned to a view of separate and independent spheres of government, which was a touchstone of dual federalism thinking.

76. 347 U.S. 272 (1954) (per curiam).

77. See note 47 supra (Court may have believed that there was no equal footing issue involved in post-admission grant); Alabama v. Texas, 347 U.S. 272, 281 (1954) (Douglas, J., dissenting) (Court treated equal footing as "frivolous and insubstantial").

78. United States v. Texas, 339 U.S. 707, 720 (1950) (plurality opinion) (quoting Coyle v. Smith, 221 U.S. 559, 566 (1911)).

79. At most, constitutional principles merely create a rebuttable presumption that states' compacts of admission grant equal seabed rights. See p. 840 infra.

80. 339 U.S. 707 (1950).

81. This right is equal, in the absence of constitutional or statutory limitations, to that of an individual disposing of land. See, e.g., South San Joaquin Irrigation Dist. v. Neumiller, 2 Cal. 2d 485, 489, 42 P.2d 64, 66 (1935); Bjerke v. Arens, 203 Minn. 501, 503, 281 N.W. 865, 866 (1938).

82. U.S. CoNST. art. IV, $\S 3$, cl. 2 (property clause); see Alabama v. Texas, 347 U.S. 272 , 273 (1954) (per curiam) ("The power over the public land thus entrusted to Congress is without limitations.")

83. States currently vary widely in geographical size and in the extent to which the federal government owns public lands within their boundaries. See, e.g., BUREAU of THE Census, U.S. Dep't of Commerce, Statistical Abstract of the United States 1977, at 197, 227 (1977). 
moreover, reveal a wide variation in the property rights possessed by particular states upon their entry into the Union. Texas and Florida, for example, came into the Union with generous grants of public lands, but most other states have received very limited property grants from Congress in their compacts of admission. ${ }^{84}$

Interpreting the statement in Texas that the equal footing doctrine has a "direct effect on certain property rights," ${ }^{8 \bar{v}}$ specifically on the right to exploit submerged lands, remains a problem. This finding can be harmonized with the holding in Alabama $v$. Texas ${ }^{86}$ only if Texas is understood to have involved statutory interpretation of the equal footing clause in the state's act of admission. ${ }^{87}$ The act did not discuss the submerged lands issue, so the Texas plurality faced the question whether the state could retain prior title by implication. The Court plurality held only that the Constitution prevented such an implication, not that Congress could not, if it had so desired, have made an explicit grant of title. ${ }^{88}$ The constitutional language supported the plurality's presumption that Texas had no greater property rights than other states. Such a presumption could have been rebutted by a showing of an express provision in the compact of admission that vested dominion in the incoming state. ${ }^{89}$

The Court in Pollard's Lessee v. Hagan ${ }^{90}$ held that property rights to the beds of inland waters belong to the states. ${ }^{91}$ The Tidelands Cases reached the opposite result for offshore lands, because "national in-

84. Unlike other states, Texas was allowed to retain its vacant and unappropriated lands. This retention was permitted in order that the state would be able to pay the debts and liabilities it had incurred as a Republic. Joint Resolution for annexing Texas to the United States, J. Res. 8, 28th Cong., 2d Sess. 797 (1845); see P. Gates, History or Public Land Law Development 316 (1968) (at admission, Florida was granted 62\%, Louisiana $38 \%$, and Alaska $28 \%$ of public land areas with remainder retained by federal government).

85. 339 U.S. at 716 (plurality opinion).

86. 347 U.S. 272 (1954) (per curiam).

87. See United States v. Texas, 339 U.S. 707, 715 (1950) (plurality opinion) (plurality held that dominium over Texas's seabed vested in federal government because " 'equal footing' clause of the Joint Resolution admitting Texas to the Union disposes of . . . the controversy" of control over area).

88. See p. 838 supra.

89. The Texas plurality found that Texas's historical proof of dominium, while a Republic, over its three marine leagues seabed was insufficient to overcome the presumption that such dominium had been relinquished. United States v. Texas, 339 U.S. 707, 717-18 (1950). Subscquently, the Maine Court held that Congress had exercised its "paramount national powers" by transferring seabed rights to the states in the Submerged Lands Act. United States v. Maine, 420 U.S. 515, 524 (1975). It thus appears that Congress can disavow federal control conferred by the equal footing doctrine over the seabed bordering any state by an express provision in the compact of admission.

90. 44 U.S. (3 How.) 212 (1845).

9I. Id. at 230; see p. 830 supra. 
terests, responsibilities, and therefore national rights are paramount."92 The Alabama Court assumed, without so deciding, that seabed rights were mere property rights. ${ }^{93}$ The failure of the Alabama Court lay in not overturning the holding in the Tidelands Cases that seabed rights were interests "so subordinated to political rights as in substance to coalesce and unite in the national sovereign." ${ }^{\prime}$ By upholding the federal power to cede submerged lands, the Alabama Court overturned the reasoning of Texas"s that although "dominium and imperium are normally separable and separate," in some cases "property interests are so subordinated to the rights of sovereignty as to follow sovereignty."96 No apparent reason exists to allow the separation of property from sovereignty in statutes like the Submerged Lands Act, while preventing such a separation in acts of admission. Therefore, the constitutionally based presumption of federal control over the seabed imposed by the equal footing doctrine can be overcome. Puerto Rico need only secure Congress's agreement to an express grant in its act of admission.

\section{Seabed Rights as Property Rights}

The Court has ruled that a grant of three marine leagues to some states does not undermine the constitutional equality of states. ${ }^{97}$ The question remains whether a congressional grant of seabed rights of 200 miles to Puerto Rico on admission to the Union would be an unconstitutional "subtraction in favor of" Puerto Rico "from the national sovereignty of the United States." 98 Such a grant would not, however, compromise national supremacy ${ }^{99}$ for the right to exploit the seabed, under both American and international law, is alienable. ${ }^{100}$ Such a

92. United States v. California, 332 U.S. 19, 36 (1947); see United States v. Texas, 339 U.S. 707, 719 (1950) (plurality opinion); United States v. Louisiana, 339 U.S. 699, 704 (1950).

93. 347 U.S. at 273 (per curiam).

94. United States v. Texas, 339 U.S. 707, 719 (1950) (plurality opinion).

95. See p. 834 supra.

96. 339 U.S. at 719 (plurality opinion) (footnote omitted). But cf. p. 840 supra (harmonizing results of Alabama and Texas).

97. Alabama v. Texas, 347 U.S. 272, 273-74 (1954) (per curiam) (upholding constitutionality of Submerged Lands Act).

98. United States v. Texas, 339 U.S. 707, 719 (1950) (plurality opinion).

99. To avoid confusion, this discussion will use national "supremacy" to refer to the sovereignty of the federal as against the state governments. This concept involves federal supremacy in the areas designated by the Constitution. The word "sovereignty" in the international sense denotes the plenary powers of individual nations as against one another and will be used as such throughout this discussion.

100. See p. 834 supra; p. 843 infra.

The Commonwealth of Puerto Rico can claim the sovereign right to explore and exploit its seabed under international law. The Continental Shelf Convention, supra note 
grant should be upheld against any equal footing challenge by other states $^{101}$ or by the Justice Department. ${ }^{102}$

Congress, a court should hold, can alienate seabed rights in any way it chooses. It may, for example, make such an express provision in a compact of admission, because a commingling of sovereignty with property rights is no more essential in the 200-mile zone than it is in the smaller zone at issue in Alabama v. Texas. ${ }^{103}$ Any other conclusion would be at odds with principles of American and international law that have recognized not only the difference between imperium and dominium over the seabed, but also the difference between sovereignty over the sea and sovereignty over the seabed. ${ }^{104}$

The Truman Proclamation, ${ }^{105}$ the first claim by a major coastal nation to rights over the continental shelf and its resources, ${ }^{100}$ avoided use of the word "sovereignty" and only referred to "jurisdiction and control" in order to signify that the United States' claim extended only to the right to exploit the resources of the shelf, not to sovereignty

4, which the United States has ratified, states that "[t]he coastal State exercises over the continental shelf sovereign rights for the purpose of exploring it and exploiting its natural resources," id. art 2(1). In the North Sea Continental Shelf Cases, the International Court of Justice held that the right to explore the continental shelf and exploit its natural resources was inherent in the coastal State-the rights existed " $i p s o$ facto and $a b$ initio." [1969] 1.C.J. 4, 22. One study has concluded that the current United States claim to the continental shelf of the Commonwealth departs from prevailing international law and practice under which overseas departments and associated states, without representative votes in metropolitan governments, exercise control over the coastal seabed. $T$. Franck, Control of Sea Resolirces by Semi-Autonomous States 27-29 (1978).

A coastal State's exclusive right to exploit the seabed does not preclude it from transferring its right, as long as the consent is express. Continental Shelf Convention, supra note 4, art. 2(2). Therefore, under international law, Puerto Rico and the United States can agree in a compact of admission who will receive the benefits of exploiting the seabed. See Submerged Lands Act: Hearings on S.J. Res. 13, S. 294, S. 107, S. 107 Amend., S.J. Res. 18 Before the Comm. on Interior and Insular Affairs, 83d Cong., lst Sess. 1066 (1953) (Jack Tate, Deputy Legal Adviser, Dep't of State) (international community unconcerned about way United States divides its rights over seabed with states) [hereinafter cited as Hearings on Submerged Lands Act].

101. In Alabama v. Texas, 347 U.S. 272 (1954) (per curiam) states challenged a disproportionate grant of seabed rights to other states. See p. 833 supra.

102. The Justice Department brought the submerged lands cases challenging the right of Gulf states to the three marine leagues limit. See United States v. Florida, 363 U.S. 121 (1960); United States v. Louisiana, 363 U.S. 1 (1960). The executive need not agree with a congressional grant of seabed rights to a state and could therefore seek to overturn a congressional grant in a compact of admission. Cf. Veto of Bill Concerning Title to Offshore Lands, 1952-1953 PuB. PAPERs 379 (Truman veto of first Submerged Lands Act). 103. 347 U.S. 272 (1950) (per curiam).

104. See Daniel, Sovereignty and Ownership in the Marginal Sea, 3 BayLor L. Rev. $243,248-56$ (1951) (distinction between ownership of seabed and sovereignty over waters, and dual rights in marginal sea).

105. Exec. Proclamation No. 2667, 3 C.F.R. 67, 68 (1945).

106. See A. Sinjela, Land-Locked States and the Contemporary Ocean Regime 303-05 (1978) (unpublished J.S.D. dissertation, Yale Law School) (on file with Yale Law Journal) (prior to 1945, few claims to continental shelf made and those made largely concerned with fishing conservation). 
over the sea. ${ }^{107}$ Both Congress and executive officials premised the Submerged Lands Act on the separability of national supremacy and property rights over the seabed. ${ }^{108}$ Finally, the separability of property and full sovereignty rights in the high seas was recently evidenced by American creation of a 200-mile zone of "exclusive fishery management authority," in which the United States claimed the power to regulate one resource of the high seas without asserting sovereignty over the area. ${ }^{109}$

The Court in United States $v$. California ${ }^{110}$ viewed the possibility of international obligations concerning the seabed as bolstering the necessity for national control of the area. ${ }^{111}$ The international community, however, has generally followed the American view that sovereign rights over the high seas are separate from exploitation rights over the resources of sea lands. ${ }^{112}$

Article 2 of the Continental Shelf Convention of the 1958 Geneva Convention on the Law of the Sea accorded to coastal states the exclusive power to exercise "over the continental shelf sovereign rights for the purpose of exploring it and exploiting its natural resources."113 The Informal Composite Negotiating Text of the ongoing Law of the Sea Conference incorporates the same provision of coastal state right to explore the shelf. ${ }^{11 t}$ Neither provision in any way prevents a coastal state from consenting to alienate these rights. ${ }^{115}$ The Composite Text

107. Exec. Proclamation No. 2667, 3 C.F.R. 67, 68 (1945); id. ("The character as high seas of the waters above the continental shelf and the right to their free and unimpeded navigation are in no way thus affected.")

108. See, e.g., Hearings on Submerged Lands Act, supra note 100, at 512-14 (Douglas McKay, Secretary of Interior) (United States controls submerged lands, regardless of property rights); S. REP. No. 133, 83d Cong., Ist Sess. 5-6, reprinted in [1953] U.S. CODE Conc. \& AD. News 1474, 1479 (Submerged Lands Act grants property rights, not constitutional rights). But see pp. 846-47 infra (federal government by invoking eminent domain can recapture any seabed grants).

109. Fishery Conservation and Management Act of 1976, Pub. L. No. 94-265, $\S \S 101-$ 102, 90 Stat. 336 (codified at 16 U.S.C. $\$ \$ 1811-1812$ (1976)).

110. 332 U.S. 19 (1947).

111. Id. at 35 .

112. See 4 M. Whiteman, Digest of International LAw 789.882 (1965) (development and acceptance of continental shelf doctrine). Some nations continue to claim that the shelf is inseparable from the high seas and therefore not subject to appropriation. See 2 Third U.N. Conference on the Law of the Sea (Caracas, Venez.) (18th mtg.) 152, U.N. SAlEs No. E. 775, v.4 (July 29, 1974) (Mr. Upadhyaya, Nepal delegate). Other nations have claimed sovereignty over both the shelf and the high seas. See 1 S. LAY, R. Churchill \& M. Nordquist, New Directions in the LAw of the SeA 15-16 (1973) (Brazilian claim of complete sovereignty).

113. Continental Shelf Convention, supra note 4, art. 2(1); see id. art. 1 (right to exploit shelf to limits of exploitability); $i d$. art. 3 ("rights of the coastal State over the continental shelf do not affect the legal status of the superjacent waters as high seas").

114. Composite Text, supra note 4, arts. $76,77(1)$ (coastal state right to exploit seabed up to distance of 200 nautical miles).

115. See id. art. 77(2) (rights to shelf exclusive unless exploration consented to by coastal state); Continental Shelf Convention, supra note 4, art. 2(2) (same). 
also proposes the creation of a 200 -mile economic zone ${ }^{116}$ under which coastal states have absolute rights "for the purpose of exploring and exploiting, conserving and managing the natural resources, whether living or non-living, of the sea-bed and subsoil and the superjacent waters." 117 In short, the right to exploit the seabed, properly defined, is simply a property right not necessarily commingled with national supremacy. Thus a grant to Puerto Rico of seabed rights at admission would not be a "subtraction in [its] favor ... from the national sovereignty of the United States." 118

\section{Seabed Grant Proposal and Its Limitations}

The equal footing doctrine's rebuttable presumption of national property rights to the seabed makes the right to exploit seabed resources a negotiable condition in Puerto Rico's bargaining for admission. ${ }^{119}$ Therefore Puerto Rico should seek a specific grant of seabed rights in a compact of admission. The federal government can, however, constitutionally regulate or terminate the rights to exploit the seabed secured in a compact. The main protection available for the island against a "taking" of its seabed rights is an explicit calculation of just compensation in its compact of admission.

116. The economic zone is an area " 200 nautical miles from the baselines from which the breadth of the territorial sea is measured." Composite Text, supra note 4, art. 57. In the economic zone the coastal state has absolute rights of exploitation, see note 117 infra, and jurisdiction for purposes of research, environmental preservation, and construction, see Composite Text, supra note 4 , art. $56(1)(b)$.

117. Composite Text, supra note 4, art. 56(1)(a). Control over the economic zone and control over the continental shelf involve a concomitant 200 -mile limit. See id. arts. 57, 76. Although sovereign rights for exploitation purposes are absolute in the shelf, see id. art. $77(2)$, coastal states nevertheless have an affirmative duty under certain conditions to give access to other States in the economic zone, see, e.g., id. art. 69 (land-locked state's right to participate in exploitation of economic zones of adjoining coastal states).

118. United States v. Texas, 339 U.S. 707, 719 (1950) (plurality opinion).

119. Puerto Rico's bargaining position would be strengthened if it could establish ownership of the seabed as a commonwealth. See notes 5 \& 100 supra (controversy over ownership of island's seabed; island's right to continental shelf under international law). Congress's grant to the states in the Submerged Lands Act of 1953, Pub. L. No. 83-31, $\$ 3$, 67 Stat. 30 (codified at 43 U.S.C. $\$ 1311$ (a) (1970)), was motivated by a desire to restore historic title to the states. See note 38 supra. Historic title is not, however, necessary to Puerto Rico's demands: congressional power to cede federal lands is "plenary" and "without limitation." Alabama v. Texas, 347 U.S. 272, 273-74 (1954) (per curiam). In construing the Submerged Lands Act, the Court relied on historic title to the seabed only in searching for congressional intent to grant submerged lands to the state at admission. See note 48 supra. Federal control of the island's seabed resources while it remains a commonwealth would not bar the island from claiming the resources at the time it seeks admission. 


\section{A. Considerations for a Specific Grant}

Puerto Rico may seek to include in any compact of admission language granting the island the right to explore and exploit the natural resources of the seabed to the extent recognized by the international community. ${ }^{120}$ In order to ensure that the grant of seabed rights to Puerto Rico will be sufficiently specific, the language used in other grants of seabed rights should be replicated:121 "The term "natural resources' includes, without limiting the generality thereof, oil, gas, and all other minerals,"122 including sand, gravel or coral, ${ }^{123}$ and all other living organisms sedentary to the seabed.124 Puerto Rico's demands should seek to encompass all rights recognized by the United States in international agreements. ${ }^{125}$ The grant should also follow the Submerged Lands Act in affirming the imperium rights of the United States. ${ }^{126}$

120. Current international law favors the recognition of sovereign rights over 200 miles of seabed. See Composite Text, supra note 4, arts. 56, 57. At minimum, Puerto Rico could scek the right to explore its seabed to the limits of exploitability, see note 5 supra, a right recognized in the Continental Shelf Convention, supra note 4 , art. 1 , which the United States has ratified. Ratifications and Accessions to the Conventions, U.N. Doc. Sr. LEG./3 REv. 1 (Apr. 12, 1961).

121. It is beyond the scope of this Note to propose the exact language of a seabed grant. Such language will require extensive negotiations because many problems of definition and jurisdiction exist. Cf. Note, Jurisdiction Over the Seabed: Persistent FederalState Conflicts, 12 URB. L. ANN. 291, 297-99 (1976) (establishment of baselines from which to measure state control, shifting of coastlines, and pollution and environmental controls are issues currently in dispute between federal and state governments). In addition, if the United States were to sign an international agreement such as the Composite Text, supra note 4 , before the island's bid for statehood, the language of a seabed grant would have to account for any international obligations the federal government had incurred.

122. Submerged Lands Act of 1953, § 2, 43 U.S.C. $\$ 1301(\mathrm{e})(1970)$.

123. In the Conveyance of Submerged Lands to Territories Act of 1974, Pub. L. No. 93-435, § 1, 88 Stat. 1210 (current version at 48 U.S.C. $\$ 1705$ (a) (Supp. V 1975)), the United States gave Guam, the Virgin Islands, and American Samoa title to their marginal sea. The grant excepted oil, gas, and other minerals from the grant but included "coral, sand and gravel." The inclusion of both phrases in the proposed grant would leave no doubt as to the meaning of Puerto Rico's demands for "mineral resources."

124. Composite Text, supra note 4, art. 77(4) (natural resources of shelf include "living organisms belonging to sedentary species").

125. The rights could include those agreed upon in the Composite Text, supra note 4 , if it should be ratified or in the Continental Shelf Convention, supra note 4 , which has already been ratified by the United States, see note 120 supra.

126. Submerged Lands Act of 1953, $\S 6,43$ U.S.C. $\S 1314$ (a) (1970):

[T] he United States retains all its navigational servitude and rights in and powers of regulation and control of said lands and navigable waters for the constitutional purposes of commerce, navigation, national defense, and international affairs, all of which shall be paramount to, but shall not be deemed to include, proprietary rights of ownership, or the rights of management, administration, leasing, use, and development of the lands and national resources ... vested in ... the respective States. . . . Congress viewed this section as superfluous, but included it in the Act to safeguard against 


\section{B. The Limits of a Grant to Exploit Seabed Resources}

The seabed is directly related to federal exercise of powers over national defense, the conduct of foreign affairs, world commerce, and navigation. ${ }^{127}$ In order to effect these constitutional powers, Congress is empowered both to enact laws regulating the seabed ${ }^{128}$ and to take state submerged lands. ${ }^{129}$ Congress can, therefore, subsequently regulate or take back in exercise of its constitutional powers any right that it might grant to Puerto Rico in its compact of admission.

Such regulation or taking after admission is highly probable. Federal energy and environmental policies have recently led Congress to regulate seabed mining. ${ }^{130}$ Treaties involving the seabed will likely limit exploitation by guaranteeing freedom of navigation and cable placement. ${ }^{131}$

The one safeguard that would be available to Puerto Rico if Congress were to take back seabed rights granted in a compact of admission is that provided by the Fifth Amendment: any taking by the federal government to execute its constitutional powers must include just compensation. ${ }^{132}$ If the federal government acquires ownership of the

the national sovereignty concerns expressed in the Tidelands Cases. See Hearings on Submerged Lands Act, supra note 100, at 1368 (Sen. Jackson) ("[T] ... is purely surplus anyway. If we have exclusive rights under the Constitution, there is nothing we can do to change it.")

127. The relation of the seabed to the exercise of these important federal powers is evidenced by the difficulties that concerns with military defense, foreign affairs, commerce, and navigation created in developing a consistent United States policy on the law of the sea. See Hollick, Bureaucrats at Sea, in New ERA OF OCEAN Politics 1-2 (A. Hollick \& R. Osgood eds. 1974) (law of sea encompasses complex array of issues that resulted in shifting American policies).

128. See, e.g., United States v. Rands, 389 U.S. 121, 123 (1967) ("power to regulate navigation confers upon the United States a "dominant servitude" " that empowers it to take submerged lands without compensation); United States v. Virginia Elec. \& Power Co., 365 U.S. 624, 627.28 (1961) (similar).

129. See, e.g., Oklahoma ex rel. Phillips v. Guy F. Atkinson Co., 313 U.S. 508, 534 (1941) (Congress empowered to take state's submerged lands in exercise of commerce power); California v. United States, 395 F.2d 261, 268 (9th Cir. 1968) (United States can condemn state's submerged lands but must pay compensation; lands not valueless because submerged and unused).

130. See 43 U.S.C.A. $\S 1348$ (West Supp. 1978) (safety regulations for exploitation of outer continental shelf).

131. See Composite Text, supra note 4, art. 58 (freedom of navigation in economic zone guaranteed by coastal states); $i d$. art. 79 (right to lay submarine cables and pipelines on continental shelf given to all signatories).

132. U.S. CoNst. amend. V ("nor shall private property be taken for public use, without just compensation"). Although it need not compensate states for submerged lands taken for the purpose of regulating navigation, see note 128 supra, the federal government must provide compensation for the condemnation of state property for any other public purpose. See, e.g., United States v. Carmack, 329 U.S. 230, 242 (1946); California v. United States, 395 F.2d 261, 263-64, 264 n.5 (9th Cir. 1968). 
Puerto Rican seabed or regulates it so as to constitute a "taking,"133 Puerto Rico should be reimbursed. Although environmental or navigational limitations are likely to be viewed as regulation and therefore noncompensable, ${ }^{134}$ American alienation of seabed rights by treaty should be treated as a taking. ${ }^{135}$

Even though there must be compensation for any taking, Puerto Rico's property interest in the seabed might be undervalued. To enforce the constitutional mandate of just compensation, courts rely on "the concept of market value: the owner is entitled to the fair market value of the property at the time of the taking."136 The "highest and most profitable use for which the property is adaptable and needed, or is likely to be needed in the near future" must be considered in determining the fair market value. ${ }^{137}$ Future use must be within a reasonable time, ${ }^{138}$ based on a known and provable market, ${ }^{139}$ and exploitable without substantial expenditure of capital. ${ }^{140}$ An owner, such as Puerto Rico, would be compensated for the "highest and most profitable use" to which it put its seabed at the time of taking. The

133. Although public regulation can reduce market value of private land without compensation, see, e.g., Village of Euclid v. Ambler Realty Co., 272 U.S. 365 (1926) (upholding zoning ordinance as within state's police power), an owner must be compensated if deprived of all reasonable economic use for the property regulated, see Costonis, "Fair" Compensation and the Accommodation Power: Antidotes for the Taking Impasse in Land Use Controversies, 75 Colum. L. REv. 1021, 1051 (1975) (under reasonable beneficial use test, landowner allowed reasonable economic return on property). See generally C. BERGER, LAND OWNERSHIP AND USE 630-31 (2d ed. 1975) (four proposals commonly used to reconcile "police power vs. taking").

134. See United States v. 422,978 Square Feet of Land, 445 F.2d 1180, 1184 n.7 (9th Cir. 1971) (history of Supreme Court cases holding regulation for navigational purposes noncompensable); cf. Dunham, $A$ Legal and Economic Basis for City Planning, 58 Colum. L. REv. 650, 666-67 (1958) (regulation to prevent public harm within police power and noncompensable).

135. Cf. United States v. 50 Foot Right of Way or Servitude, In, Over and Across Certain Land, 337 F.2d 956, 960 (3d Cir. 1964) (taking of land for pipeline to aid navigation noncompensable; compensable if taken for any other reasons).

136. United States v. Reynolds, 397 U.S. 14, 16 (1970) (footnote omitted); see Danforth v. United States, 308 U.S. 271, 283 (1939) (just compensation means value at time of taking).

137. United States v. 1,291.83 Acres of Land, 411 F.2d 1081, 1084 (6th Cir. 1969); see Olson v. United States, 292 U.S. 246, 255 (1934) ("highest and most profitable use" test).

138. See note 137 supra (citing cases).

139. United States v. 1,291.83 Acres of Land, 411 F.2d 1081, 1084 (6th Cir. 1969); Mills v. United States, 363 F.2d 78, 81 (8th Cir. 1966). Evidence of minerals may be used in determining the market value of land, but future demand for the mineral must have some objective support. "Mere physical adaptability to a use does not establish a market." United States v. Whitehurst, 337 F.2d 765, 771-72 (4th Cir. 1964) (footnote omitted).

140. United States v. 1291.83 Acres of Land, 411 F.2d 1081, 1084 (6th Cir. 1969); United States v. 2,635.04 Acres of Land, 336 F.2d 646, 648 (6th Cir. 1964). The mere existence of mineral deposits is not sufficient; the minerals must be exploitable. See Mills v. United States, 363 F.2d 78, 81 (8th Cir. 1966). 
minerals of the submerged land would be treated as one element affecting the market value of the lands taken, but would not be separately valued. ${ }^{141}$ Puerto Rico would not be compensated for the quantity of minerals in the lands or for any unknown minerals the lands contained. ${ }^{\mathbf{1 4 2}}$

Puerto Rico and the United States could agree that compensation be provided for those losses that courts normally find noncompensable, and could provide at admission a formula for calculating the compensation. The federal right to eminent domain cannot be abridged by contract," ${ }^{133}$ but the "Fifth Amendment does not prohibit landowners and the Government from agreeing between themselves as to what is just compensation for property taken. . . . Nor does it bar them from embodying that agreement in a contract. ..."144

Various methods of adjusting the constitutional measure of just compensation could be devised. For example, a simple reasonable return above fair market value could be agreed on to compensate for any unknown uses of the lands at the time of the taking. Second, the quantity and quality of minerals in the lands could be estimated at the time of taking and then multiplied by a fixed price per unit agreed on in the compact of admission. ${ }^{145}$ A court could be directed in the compact of admission to determine the future income stream by this multiplication method, then subtract expected cost of productionin essence, to capitalize profits. ${ }^{146}$ Puerto Rico could demand that this capitalized estimate serve as the measure of compensation.

141. Courts have not permitted separate valuation of the quantity and quality of minerals, multiplied by a fixed price per unit because such valuation is speculative and uncertain. See, e.g., Georgia Kaolin Co. v. United States, 214 F.2d 284, 286 (5th Cir. 1954); United States v. Land in Dry Bed, 143 F. Supp. 314, 317-18 (S.D. Cal. 1956); 4 J. SACKMaN, Nichols' The LAw of Eminent Domain $\$ 13.22$ (P. Rohan 3d rev. ed. 1977) (valuation of lands containing mineral resources).

142. See note 141 supra (citing cases); Mills v. United States, 363 F.2d 78, 81 (8th Cir. 1966) (minerals in land must be known and exploitable).

143. See Georgia v. Chattanooga, 264 U.S. 472, 480 (1924) (“[E]minent domain is an attribute of sovereignty .... It cannot be surrendered, and if attempted to be contracted away, it may be resumed at will." (citations omitted)); Contributors to Pa. Hosp. v. Philadelphia, 245 U.S. 20, 23 (1917) (contract restraining eminent domain "inefficacious for want of power").

144. Albrecht v. United States, 329 U.S. 599, 603 (1947) (citation omitted); see United States v. Fuller, 409 U.S. 488, 494 (1973) ("Congress may . . . provide . . that particular elements of value or particular rights be paid for even though in the absence of such provision the Constitution would not require payment.")

145. One possibility is to agree to use the fair market value of the mincrals at the time of the taking as the fixed price. Of course this method can be used only when quality and quantity can accurately be estimated.

146. One court has accepted the multiplication or capitalization of profits method in an eminent domain context. See State Highway Comm'n v. Nunes, 233 Or. 547, 559, 379 P.2d 579, 585 (1963). See generally Note, Valuation in Eminent Domain Cases-Use of the Multiplication Method in Valuing Mineral Deposits, 36 ALb. L. REv. 753 (1972) (arguing for this method). 
Although it requires speculation about future markets, technology, and return on investment, the last method is well-known in the law. ${ }^{147}$ The valuation method is irrelevant unless a taking occurs; but if seabed rights are taken, then some speculation is preferable to the alternative of noncompensation for potential minerals in the seabed.

\section{Conclusion}

The American experience with colonialism in the early half of this century ${ }^{148}$ has left the United States with responsibility for several small, economically poor dependencies. ${ }^{1+9}$ Some of these, like Puerto Rico, may seek statehood unless they are accorded a greater measure of self-government. ${ }^{150}$ Accommodations between the federal government and an incoming state such as Puerto Rico, involving, inter alia, rights to the seabed, could help the new state to overcome its economic problems. This Note has shown that for Puerto Rico the only bar to the creation of such rights is political, not legal. The question is whether the present fifty states would be willing to grant to Puerto Rico a right that states have not obtained or preserved for themselves.

147. See, e.g., State Highway Comm'n v. Nunes, 233 Or. 547, 556, 379 P.2d 579, 584 (1963) (stating that frequently impossible as practical matter not to use capitalization method in valuation); In re Atlas Pipeline Corp., 9 S.E.C. 416, $421-40$ (1941) (Chapter X of Bankruptcy Act requires courts to judge whether reorganization plans are "fair and equitable, and feasible"; judgment necessitates projections of earnings, remaining economic life, and capitalization rates for corporations); I.R.C. $\$ 167$ (projections must be made of useful life and obsolescence of assets in computing depreciation).

148. See J. Pratt, America's Colonial Experiment 58 (1950) (Spanish American IVar "opened the door of a colonial career to the United States"); Woodward, Empire Beyond the Seas, in The National Experience 518-37 (J. Blum 2d ed. 1968) (era of manifest destiny, imperialistic stirrings, and white man's burden).

149. See note 148 supra (citing sources); Letter from Ruth G. Van Gleve, Director, Office of Territorial Affairs, Dep't of the Interior (Apr. 4, 1978) (on file with Yale Law Journal) (compiling per capita income of American territories); Office of the Commonwealth of Puerto Rico, Basic Industrial Facts on Puerto Rico-1975 (1976) (reporting island's per capita income).

150. Some sentiment for statehood in the future has, for example, also been reported in the Virgin Islands. See Macridis, Political Attitudes in the Virgin Islands, in VirgiN IsLands 193, 202 (J. Bough \& R. Macridis eds. 1970).

It is conceivable that Puerto Rico would settle for less than statehood, if the arrangement conferred greater autonomy than that provided by the current commonwealth status. For example, in 1975, after two years of deliberations, the Ad Hoc Advisory Group on Puerto Rico, a committee composed of presidential appointees and delegates chosen by the Governor of Puerto Rico, made its recommendations for greater island control over its economic programs and international affairs. See REPORT OF THE AD HOC AD. visory Group on Puerto Rico, Compact of Permanent Union Between puerto Rico AND THE United States 87-100 (1975). President Ford's New Year's Eve statehood proposal, however, was made in lieu of an endorsement of the proposed compact. Text of Ford Puerto Rico Statement, N.Y. Times, Jan. 1, 1977, at 5, col. 1. The President apparently found that statehood within the American system was more attractive than a more autonomous form of commonwealth status. 